\title{
GROUNDWATER LEVEL TREND IN THE LAST DECADES IN NORTH-EASTERN PART OF ROMANIA
}

DOI: https://doi.org/10.18509/GBP210075i

UDC: 556.313.047(498)

\author{
Minea Ionuț ${ }^{1}$ \\ Boicu Daniel ${ }^{1}$ \\ Iosub Marina ${ }^{2}$ \\ Chelariu Oana-Elena ${ }^{3}$ \\ ${ }^{1}$ Alexandru Ioan Cuza" University of Iași, Faculty of Geography and Geology, Romania \\ ${ }^{2}$ Integrated Center of Environmental Science Studies in the North Eastern Region, CERNESIM, \\ "Alexandru Ioan Cuza" University of Iași, Romania \\ ${ }^{3}$ Alexandru Ioan Cuza" University of Iași, Interdisciplinary Research Department -Field \\ Science, Romania
}

\begin{abstract}
The evolution of groundwater levels is very difficult to predict over medium and long term, in any geographical conditions, in the context of global climate change and increasing human impact activities. For that is important to analyses trends of this hydrogeological parameters to estimate the evolution of underground water resources in different natural conditions. To estimate groundwater level trends, the Mann-Kendal test and Sen slope was used. In additional Innovative Trend Method (ITA) was applied to seasonal and annual groundwater level from 9 hydrogeological wells, with different depths of water, with data between 1983 to 2018. Most of the trends are related between these two methods (from 8 out of 9 hydrogeological wells). The seasonal datasets indicate that $55 \%$ of slopes values are statistically significant for summer and autumns season and $44 \%$ for annual values. The most increasing trends overlaps $+3 \mathrm{~cm} / \mathrm{year}$ (for 2 hydrogeological wells) and indicates an important decrease of groundwater volume. The results can be implemented in groundwater resources management projects at local and regional level.
\end{abstract}

Keywords: groundwater level, trends, Mann-Kendall test, ITA method, North-Eastern Romania

\section{INTRODUCTION}

The evaluation of the trends of the different hydro-climatic parametric indicators from a geographical region represents an important stage in estimating the behavior of these parameters in different scenarios of evolution of the environmental conditions. Against the background of more and more accentuated climate changes, with evolution scenarios adapted on short, medium and long term, the evaluation of the tendencies of variation of the groundwater level becomes obligatory in the water resources management projects. Practically two main directions were differentiated in the analysis of trends. The first is based on Mann-Kendall test and estimating trends by the Sen method.

The results obtained by applying to different climatic or hydrological parameters highlighted statistically significant trends of increasing average or maximum annual temperatures [1-3], precipitation [4,5] or river runoff [6,7]. Starting with 2012 [8] a new approach has been proposed to highlight these trends through graphical methods. This 
method has also been widely used for hydro-climatic parameters (maximum river runoff, maximum temperatures or maximum precipitation) [9-11] and even hydrogeological (monthly and annual groundwater level [12]. In this paper we will try to apply the two types of methodologies in identifying trends in the seasonal and annual values of groundwater level for a series of hydrogeological wells in the north-eastern part of Romania. This analysis follows the research conducted in highlighting the groundwater level trends in this area, and is intended to be a scientific support in estimating the evolution of groundwater resources in this area, in different scenarios of regional climate evolution.

\section{STUDY AREA}

The north-eastern part of Romania is characterized by the presence of hilly plain with altitudes ranges between 30 and $250 \mathrm{~m}$ situated in a temperate continental climate (Figure 1). The maximum temperatures and precipitations are registered in summer (June, respectively July) and the minimum values are recorded during the winter season (in February). The rivers flow has a maximum runoff in the spring season and a minimum in the winter, when precipitation is stored on the surface in the form of a layer of snow and ice. These hydro-climatic features along geological structure has an important influence above groundwater resources which are stationed near surface in groundwater bodies with the groundwater level varying between 2 and 10 meters.

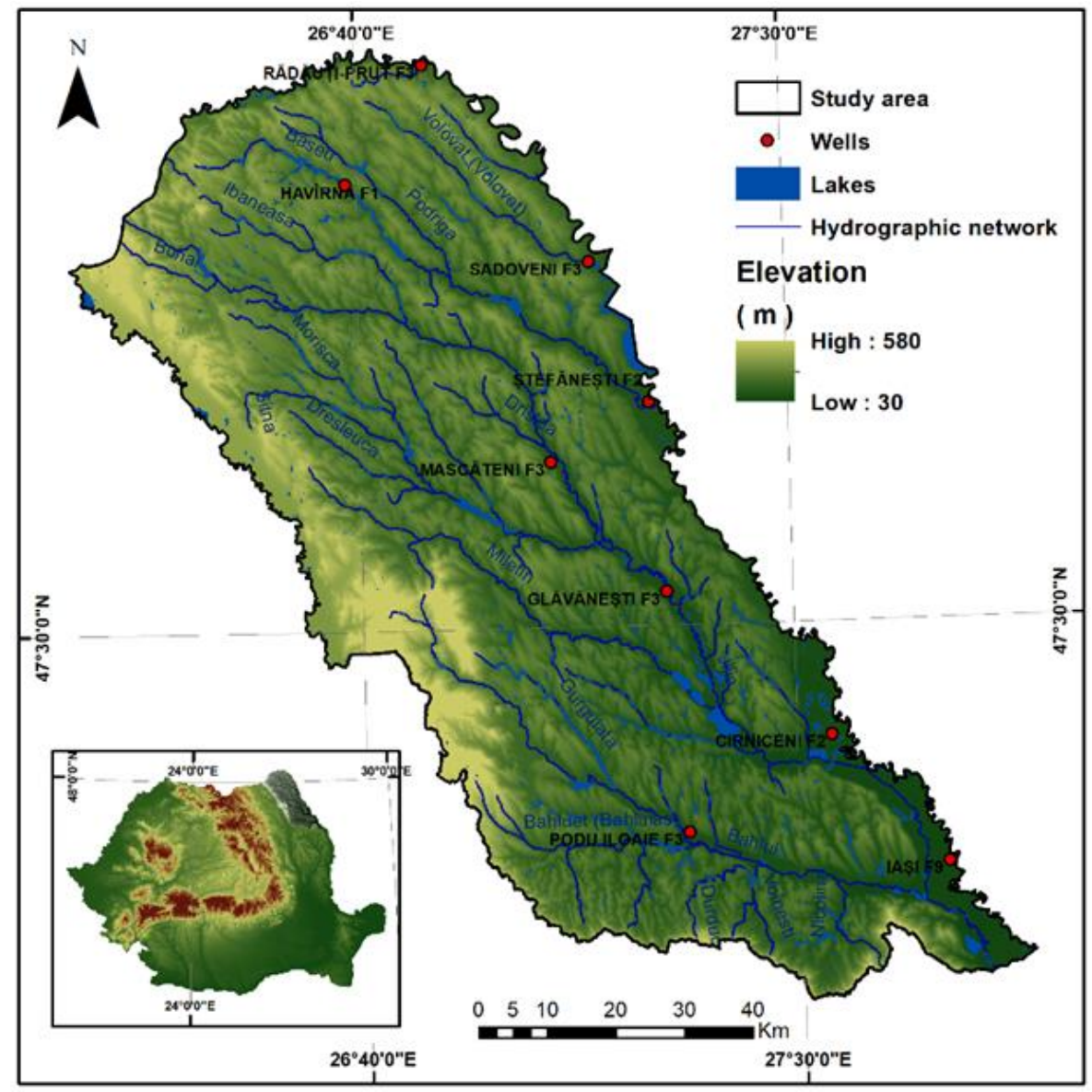

Figure 1. the position of wells in North-eastern part of Romania. 


\section{DATA SETS AND METHODOLOGY}

In order to identify the trends of the groundwater level for the northeastern part of Romania, the data referring to the seasonal and annual average levels from 9 hydrogeological wells were used. These were made by the Prut Bârlad Water Basin Branch, integrated into the "Apele Romane" National Company during 1970-1980. The period taken into account is from 1983 to 2018. For the present analysis were used data from hydrogeological wells with different depths, located mostly in the major bed of the hydrographic network that drains this region.

To estimate trends of groundwater level the Mann-Kendall test for trend and Sen's slope estimates was used. The Mann-Kendall test is applicable in cases when the data values xi of a time series can be assumed to follow the equation [13]:

$$
\mathrm{x}_{\mathrm{i}}=f\left(t_{i}\right)+\varepsilon_{\mathrm{i}}
$$

where: $f(t)$ is a continuous monotonic increasing or decreasing function of time and the residuals $\varepsilon i$ can be assumed to be from the same distribution with zero mean. It is therefore assumed that the variance of the distribution is constant in time. Then the null hypothesis of no trend, $H_{0}$, is tested in order to accept or reject it. The $x_{\mathrm{i}}$ observations are randomly ordered chronologically, against the alternative hypothesis, $H_{l}$, where there is an increasing or decreasing monotonic trend [14].

To estimate the slope of an existing trend, the Sen's nonparametric method is used. It may be used if the trend can be assumed to be linear accordingly with the equation:

$$
f(t)=S t+B
$$

where: $S$ is the slope; $B$ is a constant.

To get the slope estimate in previous equation the slopes of all data value pairs are calculated using the formula:

$$
S_{i}=\frac{x_{i}-x_{k}}{j-k}
$$

where: $i=1$ to $n ; x j$ and $x_{k}$ are data values at times $\mathrm{j}$ and $k(j>k)$, respectively.

If there are $\mathrm{n}$ values $\mathrm{xj}$ in the time series, we get as many as $N=n(n-1) / 2$ slope estimates Si. The Sen's estimator of slope is the median of these $N$ values of $S i$. The $N$ values of $S i$ are ranked from the lowest to the highest and the Sen's estimator $(S)$ is differently calculated if $N$ is odd or even. Thus,

$$
S=S_{[(N+1) / 2]} \text {, if } N \text { is odd and } S=\frac{1}{2}\left\{S_{(N / 2)}+S_{[(N+2) / 2]}\right\} \text {, if } N \text { is even }
$$

Statistical analysis of trends use different significance levels $(\alpha=0.001,0.01,0.05$, or 0.1 ) and for this study we retained only the level of $\alpha=0.05$.

This method was largely used to detect trends in climatic and hydrological data series [15, 16]. In Romania, the same methodology has also been used with very good results to identify trends in different data series (temperature, precipitations, rivers discharge etc.) [17-19].

Innovative Trend Method (ITA) proposed by Șen [8] simplifies the way of estimating the trends by graphically representing the analyzed values. Initially, the data series is divided into two series, which are then represented graphically in the scatter-plot system. 
Depending on the position of the representation points, the tendency of increase, decrease or constant of the analyzed parameters can be estimated. At the same time, the trend of the data string can be estimated by applying the formula [20]:

$$
\mathrm{s}=\frac{2\left(\overline{y_{2}}-\overline{y_{1}}\right)}{n}
$$

where: $s$ is the slope of the trend, $\overline{y_{1}}, \overline{y_{2}}$ are the averages of the first and second series, and $n$ is the total number of data. An important aspect must be mentioned in the analysis of the results. Taking into account the fact that in the case of groundwater level the actual measurements are related to the land surface, the interpretation of the trends is made inversely to the interpretation of the trends in the case of hydro-climatic parameters. (Figure 2).
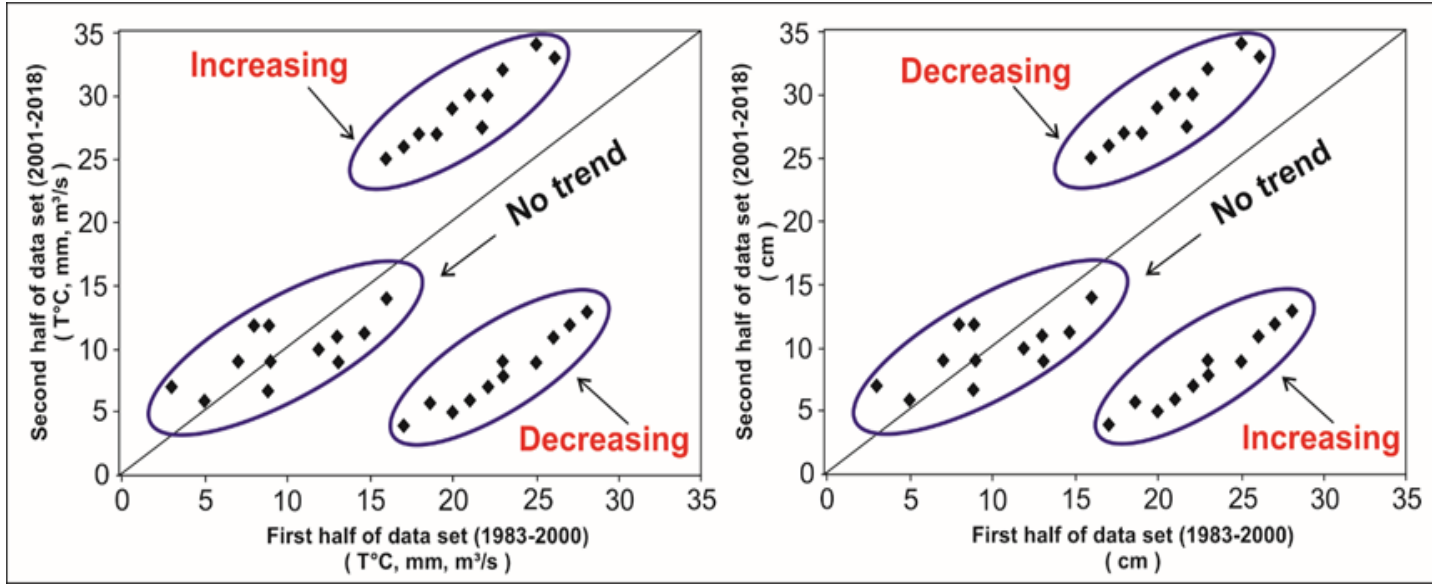

Figure 2. Graphical interpretation for climatic and hydrological parameters (A) and groundwater level (B) trends using ITA [12]

\section{RESULTS}

By applying the specific methodologies described above, a series of results have been obtained that highlight the positive or negative trends of groundwater level variation in recent decades. The slope values obtained by applying the Mann-Kendall test and the Sen's nonparametric method show that in $44 \%$ of the hydrogeological wells analyzed the results obtained are statistically significant for the annual values.

Table 1. Slopes for groundwater level trends using Mann-Kendal test and the Sen's nonparametric method

\begin{tabular}{|l|l|c|c|c|c|c|c|}
\hline No. & Well code & $\begin{array}{c}\text { Average } \\
\text { depth }(\mathbf{m})\end{array}$ & Winter & Spring & Summer & Autumn & Annual \\
\hline $\mathbf{1}$ & RĂDĂUȚI-PRUT F3 & 13 & $-2.03^{*}$ & $-2.16^{*}$ & $-1.70^{*}$ & $-1.91^{*}$ & $-2.17^{*}$ \\
\hline $\mathbf{2}$ & HAVÎRNA F1 & 2.5 & -0.94 & -1.46 & 0.11 & -0.05 & -0.31 \\
\hline $\mathbf{3}$ & SADOVENI F3 & 9 & $3.78^{*}$ & $3.39^{*}$ & $2.84^{*}$ & $3.31^{*}$ & $3.41^{*}$ \\
\hline $\mathbf{4}$ & ȘTEFĂNEȘTI F2 & 6 & 0.28 & 0.08 & 0.19 & 0.03 & 0.08 \\
\hline $\mathbf{5}$ & MASC̆̆TLNI F3 & 6.5 & $1.98^{*}$ & 1.61 & $2.56^{*}$ & $2.03^{*}$ & $2.22^{*}$ \\
\hline $\mathbf{6}$ & GLĂVĂNEȘTI F3 & 5 & -0.18 & -0.62 & -0.29 & -0.29 & -0.44 \\
\hline $\mathbf{7}$ & CIRNICENI F2 & 5 & $3.68^{*}$ & $3.88^{*}$ & $3.65^{*}$ & $3.57^{*}$ & $3.81^{*}$ \\
\hline $\mathbf{8}$ & PODU ILOAIE F3 & 2 & -0.6 & -0.83 & -0.91 & -0.21 & -0.42 \\
\hline $\mathbf{9}$ & IAȘI F9 & 5 & 1.01 & 1.44 & $1.74^{*}$ & $1.70^{*}$ & 1.38 \\
\hline
\end{tabular}

\footnotetext{
*values wist statistical significante for $\alpha=0,05$
} 
The same weight is kept in the case of values corresponding to the winter season. The most statistically significant results were obtained for the summer and autumn seasons (over 55\%). At 30\% of the analyzed hydrogeological wells (Rădăuti-Prut F3, Sadoveni F3, Cirniceni F2) the statistical significance of the slopes obtained by this method was maintained throughout the year. At two other wells (Mascateni F2 and Iasi F9) there are slopes with high statistical significance within the annual and seasonal values. In wells with higher groundwater depths, the slope values remain high (regardless of the trend throughout the year, Figure 2). It should be mentioned that in the case of groundwater level trends the interpretation of the results must be done in reverse to the interpretation of the trends in the case of surface hydro-climatic parameters. The highest values of the trends $+3.81 \mathrm{~cm} /$ year at Cirniceni F2 and $+3.41 \mathrm{~cm} /$ year at Sadoveni F3 show a clear tendency of decreasing groundwater level relative to the land surface. Practically in 5 of the 9 boreholes 9 ( 4 having statistically significant values) the tendency to deepen the groundwater level is obvious.

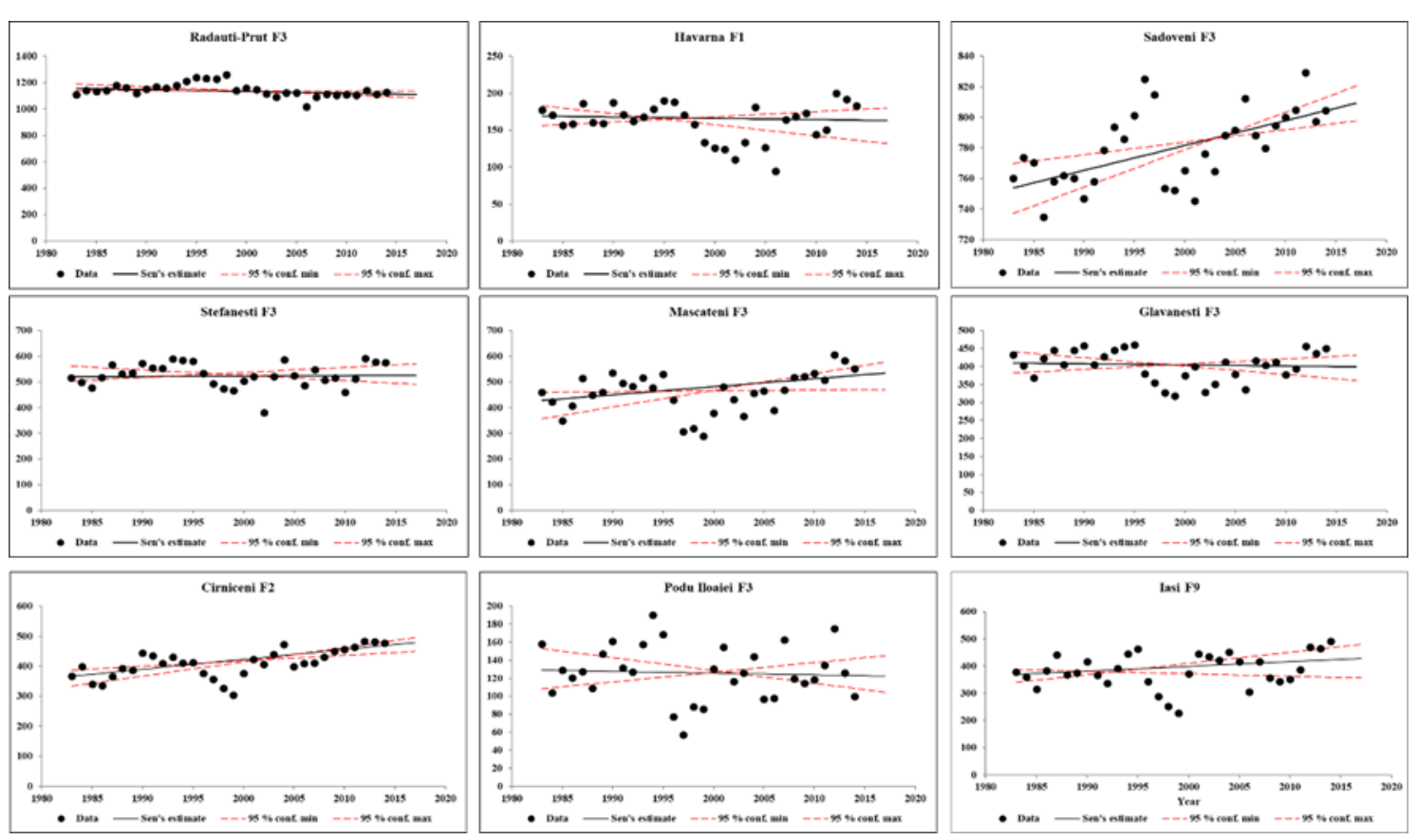

Figure 3. Annual trends of groundwater level for different wells in north-eastern part of Romania using Mann-Kendall test

In the spring and summer seasons due to the marked variations of the monthly average values of the groundwater level under the impulse of the hydric water supply from the surface (from precipitations or hydrographic network) the slopes of the trends have the lowest significance [21] (Figure 3). In hydrogeological wells with less deep groundwater relative to the land surface (Havarna F1 and Podu Iloaiei F3) the trends remain negative, but the statistical significance of the results is low.

The application of the ITA method highlighted the same trends in 8 of the 9 hydrogeological wells analysis. The only wells where the trend is different between the two applied methods is Stefanesti F2 which by the ITA method has a negative groundwater level variation trend, and by the Mann-Kendal method a positive one (Table 2 ). This divergence can be explained by the influence given by the presence of a large accumulation lake near this hydrogeological drilling (Stanca-Costesti lake, at the eastern border between Romania and the Republic of Moldova) which substantially changes the 
water supply infiltrated underground in this area. In general, slope values are lower (in the case of positive trends) and higher (in the case of negative trends) than the values obtained by the Mann-Kendall test and the Sen's nonparametric method.
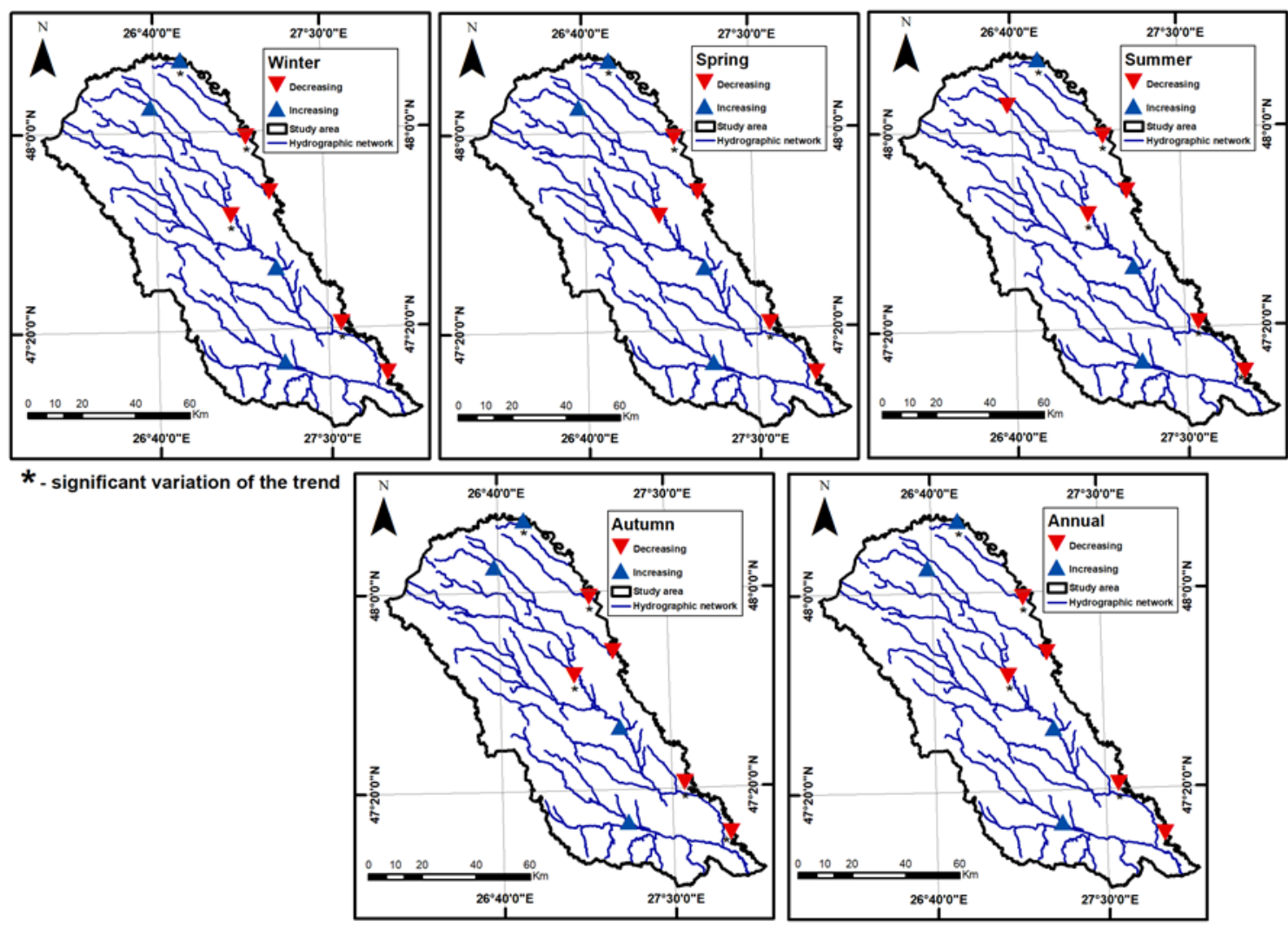

Figure 4. the seasonal and annual trends of groundwater level in north-eastern part of Romania using Mann-Kendall test

The annual trends of groundwater level by the ITA method are more clearly highlighted in the case of the Radauti Prut F3, Cîrniceni F2 and Iași F9 wells (Figure 4). The same clear evidence of the trends is kept at seasonal level with the mention that in the case of hydrogeological wells: Sadoveni F3, Mascateni F3 and Podu Iloaiei F3, on the graph representing the trends (figure 8) they seem to remain relatively constant (Figure 5).

Table 2. Slopes of groundwater level trends using ITA method.

\begin{tabular}{|l|l|c|c|c|c|c|c|}
\hline No. & \multicolumn{1}{|c|}{ Well code } & $\begin{array}{c}\text { Average } \\
\text { depth }(\mathbf{m})\end{array}$ & Winter & Spring & Summer & Autumn & Annual \\
\hline $\mathbf{1}$ & RĂDĂUȚI-PRUT F3 & 13 & -3.21 & -3.72 & -4.9 & -3.72 & -3.92 \\
\hline $\mathbf{2}$ & HAVÎRNA F1 & 2.5 & -1.31 & -1.81 & -1.12 & -0.92 & -1.35 \\
\hline $\mathbf{3}$ & SADOVENI F3 & 9 & 0.21 & 1.18 & 0.57 & 0.69 & 0.85 \\
\hline $\mathbf{4}$ & ȘTEFĂNEȘTI F2 & 6 & -0.81 & -1.41 & -1.21 & -1.15 & -1.16 \\
\hline $\mathbf{5}$ & MASCĂTENI F3 & 6.5 & 1.12 & 0.87 & 2.12 & 2.53 & 1.53 \\
\hline $\mathbf{6}$ & GLĂVĂNEȘTI F3 & 5 & -1.52 & -2.31 & -1.32 & -0.89 & -1.56 \\
\hline $\mathbf{7}$ & CIRNICENI F2 & 5 & 2.42 & 2.72 & 2.62 & 3.26 & 2.78 \\
\hline $\mathbf{8}$ & PODU ILOAIE F3 & 2 & -0.33 & -1.05 & -0.33 & -0.36 & -0.5 \\
\hline $\mathbf{9}$ & IAȘI F9 & 5 & 0.87 & 0.98 & 2.51 & 2.31 & 1.62 \\
\hline
\end{tabular}



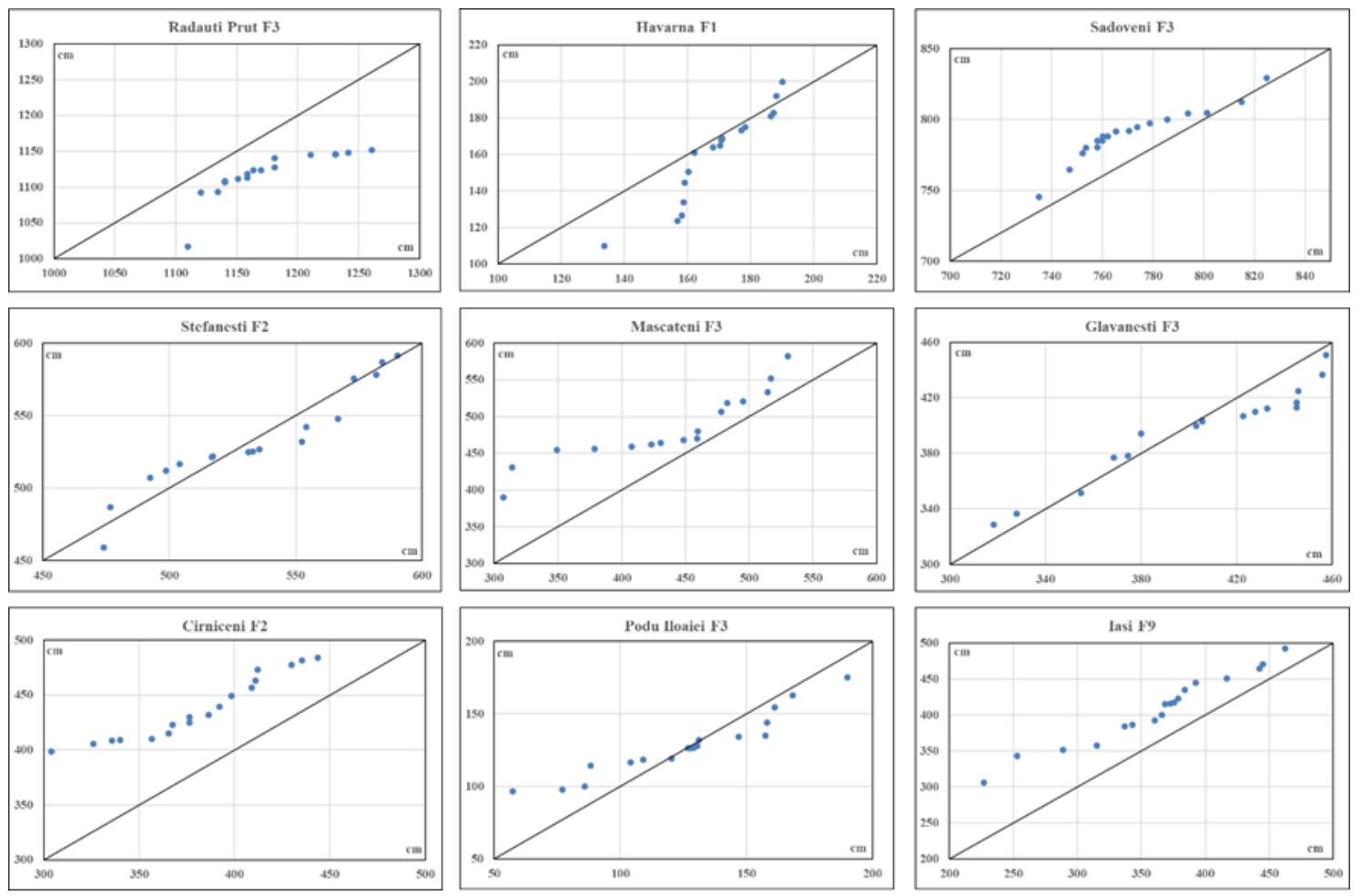

Figure 5. Annual trends of groundwater level for different wells in north-eastern part of Romania using ITA method.
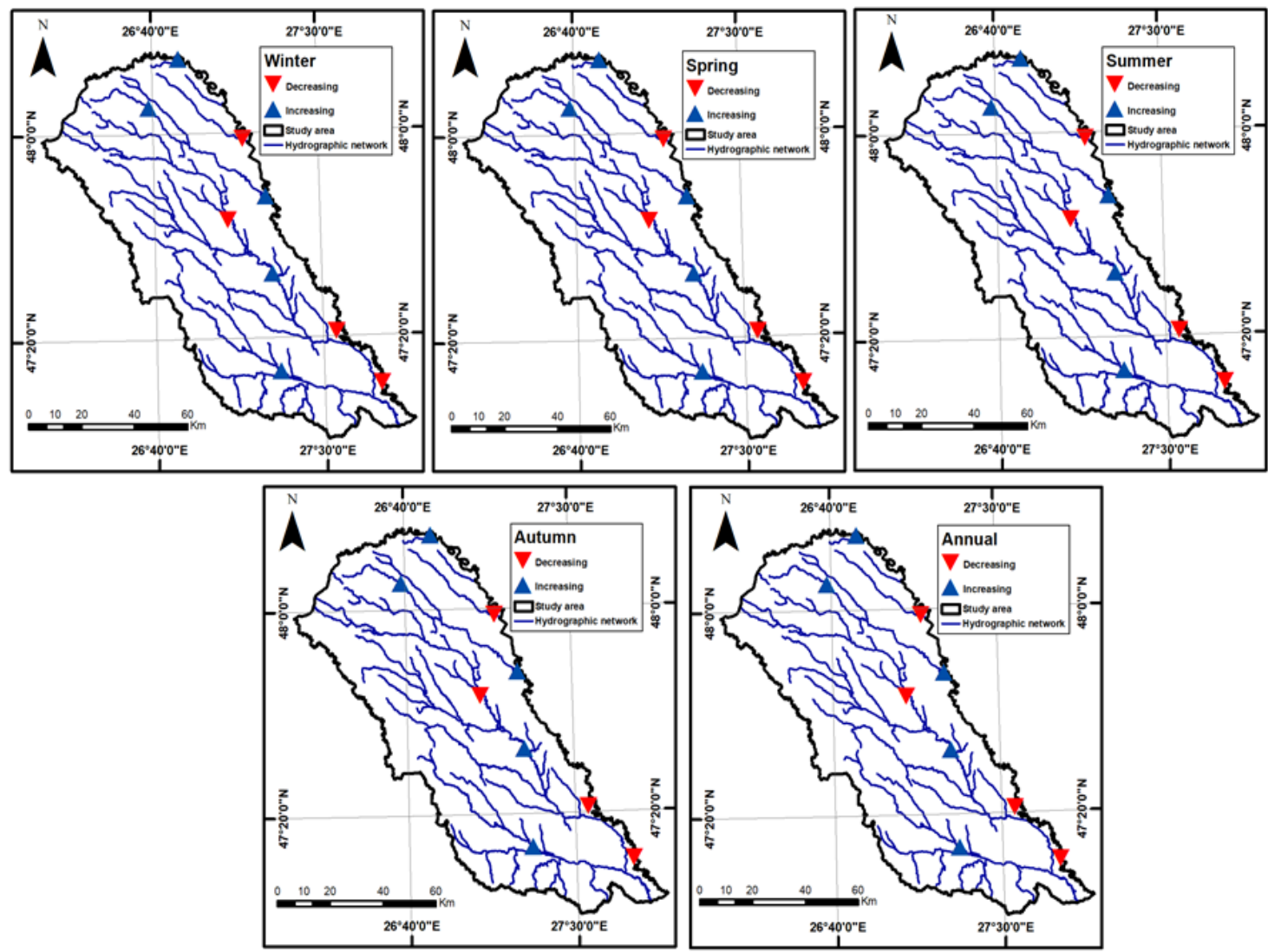

Figure 6. Seasonal trends of groundwater level for different wells in north-eastern part of Romania 


\section{CONCLUSIONS}

Following the analysis, a series of conclusions can be drawn that can be helpful in groundwater resources management projects at local and regional level. First of all, both methods can be applied to highlight the trends of groundwater level variations, the results obtained, in terms of the trend sign being identical in over $88 \%$ of cases. The values obtained using the Mann-Kendall test and the Sen's nonparametric method have a higher statistical significance (in 55\% of cases in the analysis of data on summer and autumn seasons and $44 \%$ in the case of data on annual values of groundwater level). The ITA method, even if it is more expeditious, and the obtained results have a lower statistical significance, has the advantage of easier graphical identification of the trends of groundwater levels variations. At the same time, we consider that the trends obtained for seasonal and annular groundwater level can be correlated with the trends obtained by the same methods in the case of hydro-climatic parameters from the surface (precipitation, river runoff, etc.).

\section{Acknowledgement}

This work was supported by a grant of the Romanian Ministry of Education and Research CNCS-UEFISCDI, project number PN-III-P1-1.1-TE-2019-0286, within PNCDI III. The authors are grateful for the hydrogeological data provided by the Prut Barlad Basin Branch of the Romanian National Water Administration.

\section{REFERENCES}

[1] Croitoru A.E., Drignei D., Dragotă C.S., Imecs Z., Burada D.C., Sharper Detection of Winter Temperature Changes in the Romanian Higher-Elevations, Global and Planetary Change. Vol. 122, pp 122-129. 2014.

[2] Dumitrescu A., Bojariu R., Bîrsan M.V., Marin L., Manea A., Recent climatic changes in Romania from observational data (1961-2013), Theor. applied climatology, 19, 1, 111-119, 2014.

[3] Croitoru, A.E., Piticar A, Sfica L, Harpa GV. Rosca C.F., Tudose T, Horvath C, Minea I., Ciupertea F.A., Scripca A.S., Extreme Temperature and precipitation Events in Romania, Romanian Academy Press, Bucharest, 2018.

[4] Tabari H, Hosseinzadeh Talaee P., Analysis of trends in temperature data in arid and semiarid regions of Iran, Glob Planet Change, 79, 1-10, 2011.

[5] Bürger G., On trend detection. Hydrological Processes, 31, 4039-4042, 2017.

[6] Croitoru AE, Minea I., The impact of climate changes on rivers discharge in Eastern Romania. Theor Applied Climatol, 1434-4483, 2015.

[7] Bîrsan M.V., Zaharia L., Chendes V., Branescu E., Seasonal trends in Romanian streamflow, Hydrol. Processes, 28 (15), 4496-4505, 2014.

[8] Şen, Z., Innovative trend analysis methodology. J Hydrol Eng 17, 1042-1046, 2012.

[9] Tabari, H., Taye, M.T., Onyutha, C., \& Willems, P., Decadal analysis of river flow extremes using quantile-based approaches. Water Resour Manag 31, 3371-3387, 2017.

[10] Wu, H., \& Qian, H., Innovative trend analysis of annual and seasonal rainfall and extreme values in Shaanxi, China, since the 1950s. Int J Climatol 37, 2582-2592. 2017.

[11] Wu, H., Li, X., \& Qian, H., Detection of anomalies and changes of rainfall in the Yellow river basin, China, through two graphical methods. Water 10, 19, 2018. 
[12] Minea I., Boicu D., Chelariu O.E., Detection of Groundwater Levels Trends Using Innovative Trend Analysis Method in Temperate Climatic Conditions, Water, 12, 2020.

[13] Salmi T., Määttä A., Anttila P., Ruoho-Airola T., Amnell T., Detecting trends of annual values of atmospheric pollutants by the Mann-Kendall test and Sen's slope estimates - the Excel template application MAKESENS. Publications on Air Quality, No. 31, Finnish Meteorological Institute, Helsinki, Finland, 2002.

[14] Minea I., Croitoru A.E., Groundwater response to changes in precipitation in north-eastern Romania, Environmental Engineering Management Jour., 16, 3, 643-651, 2017.

[15] Zhang X., Aguilar E., Sensoy S., Melkonyan H., Tagiyeva U., Ahmed N., Kutaladze N., Rahimzadeh F., Taghipour A., Hantosh T.H., Albert P., Semawi M., Karam A.M., Al-Shabibi H.S. M., Al-Oulan Z., Zatari T., Al Dean Khelet I., Hammoud S., Demircan M., Eken M., Adiguzel M., Alexander L., Peterson T., Wallis T., Trends in middle east climate extremes indices during 1930-2003, Journal of Geophysical Research, 110, (D22104),1-12, 2005.

[16] El Kenawy A., Lopez-Moreno J.I., Vicente-Serrano S.M., Recent trends in daily temperature extremes over northeastern Spain, Natural Hazards and Earth System Science, 11, 2583-2603, 2011.

[17] Minea I., Hapciuc O.E. Banuc G. Jora I., Trends and variations of the groundwater level in the north-eastern part of Romania, International Multidisciplinary Scientific Geoconferences, SGEM 2016, 30 June 6 July 2016 Bulgaria, 16th GeoConference on Water resources, Forest, Marine and Ocean Ecosystems, Conference Proceedings, Volume I, Hydrolgeology, Engeneering Geology and Geotectonics 1053-1060, 2016.

[18] Minea I., Boicu, D., Iosub M., Chelariu O.E. Solomon B., Long-term trends in river flow from North-eastern part of Romania, International Multidisciplinary Scientific GeoConference on Water resources, Forest, Marine and Ocean Ecosystems, Conference Proceedings, Volume I, Hydrology and Water Resources, SGEM 2020, Conference Proceedings, vol.20, 225-231, 2020.

[19] Minea I. The Vulnerability of Water Resources from Eastern Romania to Anthropic Impact and Climate Change. In: Negm A., Romanescu G., Zeleňáková M. (eds) Water Resources Management in Romania. Springer Water. Springer, Cham, 229-250, 2020.

[20] Şen Z., Innovative trend significance test and applications. Theoretical and Applied Climatology, 127, 939-947, 2017.

[21] Minea I., Croitoru A.E., Climate Changes and their impact on the variation of groundwater level in the Moldavian Plateau (Eastern Romania), International Multidisciplinary Scientific Geoconferences, SGEM 2015, Conference Proceedings, Vol I, Hydrology and Water Resources, 137-145, 2015. 